\title{
THE POTENTIALS OF CROSS-BORDER TOURISM DEVELOPMENT IN THE LOWER-TISA VALLEY
}

\author{
Bettina TóTH* \\ University of Szeged, Faculty of Science and Informatics, Department of Economic and \\ Social Geography 2 Egyetem utca, 6722, Szeged, Hungary, e-mail: bettina.toth3@gmail.com

\section{György VIDA} \\ University of Szeged, Faculty of Science and Informatics, Department of Economic and \\ Social Geography 2 Egyetem utca, 6722, Szeged, Hungary, e-mail: vidagyorgy.vida@gmail.com

\section{Gábor LADOS} \\ University of Szeged, Faculty of Science and Informatics, Department of Economic and \\ Social Geography 2 Egyetem utca, 6722, Szeged, Hungary, e-mail: ladosg.szte@gmail.com

\section{Zoltán KOVÁCS} \\ University of Szeged, Faculty of Science and Informatics, Department of Economic and Social Geography, \\ 2 Egyetem utca, 6722, Szeged, Hungary, e-mail: zkovacs@geo.u-szeged.huResearch Centre for \\ Astronomy and Earth Sciences, Geographical Institute, Budapest, Hungary, e-mail: zkovacs@iif.hu
}

Citation: Tóth, B., Vida, G., Lados, G. \& Kovács, Z. (2020). THE POTENTIALS OF CROSSBORDER TOURISM DEVELOPMENT IN THE LOWER-TISA VALLEY. GeoJournal of Tourism and Geosites, 28(1), 360-375. https://doi.org/10.30892/gtg.28128-475

\begin{abstract}
Recent trends in European spatial development show that unexplored border regions have huge potentials for tourism development, what can, on the one hand, positively influence their economic performance, and on the other hand, provide good opportunities for cross-border cooperation. This paper aims to investigate the potentials of tourism development along the Serbian and Hungarian sections of the Tisa river. The analysis of socio-demographic conditions was based on data of the 2001 and 2011 population census, in addition, tourist attractions on both sides of the border were collected and catalogued. Results show that the Hungarian-Serbian border region provides good opportunities for tourism development, which may enhance cooperation among local actors, including municipalities and entrepreneurs.
\end{abstract}

Key words: tourism development, cross-border cooperation, border regions, tourist attractions, Tisa

\section{INTRODUCTION}

Since the fall of the 'Iron Curtain' geographical research on cross-border cooperation has intensified. During the Cold War international boundaries often

\footnotetext{
* Corresponding author
} 
constituted rigid spatial barriers. People on both sides of international boundaries lived at dead ends, with limited and controlled contacts between them. Economic development was hindered by the lack of investments and limited opportunities for cross-border cooperation. Under such circumstances border regions often became peripheralized which resulted in the outmigration of skilled people and a subsequent social erosion (Lang, 2015). After 1989, as 'European integration' intensified, borderlands gained an impetus for more prosperous economic development throughout Europe. EU launched cross-border cooperation programmes to overcome barriers and differences in structures, to compensate for peripheral location and unequal development, and to design border regions that allow the local populations to improve economically and to interact culturally and socially (Wastl-Walter, 2009). The role of tourism as a tool of cross-border cooperation and regional development has been continuously strengthening within the EU (Bujdosó et al., 2015). Tourism related cross-border development requires new forms of cooperation from nation states, especially along the Schengen border (Zaitseva et al., 2016). Recent examples show that the role of rivers in cross border tourism development is increasing (Kropinova, 2013). This is the point of departure for this paper which aims to investigate the potentials of tourism development along the Serbian and Hungarian sections of the Tisa river. The Tisa is one of the main rivers in East Central Europe with a length of $966 \mathrm{~km}$, connecting five post-socialist countries: Ukraine, Romania, Slovakia, Hungary and Serbia (Nagy et al., 2019). Opportunities for tourism development are especially favourable in the lower section of the river (i.e. south of Szolnok), where the Tisa is navigable and there are bigger centres (e.g. Szeged, Szentes, Zrenjanin, Becej) that can serve as catalysts for regional tourism development.

The main research questions this paper would like to address are as follows:

- What are the general socio-economic conditions in the Lower-Tisa Valley on both sides of the Serbian-Hungarian border, and how they relate to the wider surroundings?

- What types of tourism attractions can be found in the region?

- What are the potentials for long-term coordinated tourism development?

- What kind of policy recommendations can be formulated in the light of international experiences?

The rest of this paper is organized as follows. First, we review the literature on the geographical challenges of border regions and the possible role of cross-border tourism development. We then discuss the data collection and research methodology. A section then follows with main findings of the research and the key tourist attractions and their potentials. Finally, we turn back to the main research questions discuss the results in the light of international experiences, present our conclusions and formulate policy recommendations.

THE CHALLENGES OF BORDER REGIONS AND THE ROLE OF TOURISM DEVELOPMENT

Border regions are special areas within the European Union. The EU defines border zones as areas within $25 \mathrm{~km}$ from the EU boundary, hence there are many NUTS 3 level units which are classified as border regions, however, not all of them connect directly with the border line, and there are excessive areas of NUTS3 regions that lie much farther away from the boundary than $25 \mathrm{~km}$ (Eurostat, 2018). In 2014 approximately one third of the EU population lived in border regions while only $28 \%$ of the total GDP originated from there, and the per capita GDP values were only $88 \%$ of the EU average (European Commission, 2017). Thus, border regions not only concentrate a significant part of the EU population, but they are generally lagging behind in socio-economic development compared to other non-border regions. This is also acknowledged by the Union as in the 2014-2020 development period, $€ 6.6$ billion has been allocated to 60 cross-border cooperation programmes (European Commission, 2017, 126). In addition, these regions 
often show weaknesses in providing adequate infrastructure, high quality services, and well-paid jobs. Thus, a general symptom of border regions that they face difficulties in retaining people. Due to these factors border regions constitute long-term challenges for all member states, but as Table 1 clearly indicates post-socialist countries are especially hard-hit by the shrinkage and demographic erosion of border regions. Therefore, the issue has special relevance in the regional development policy of these countries.

\begin{tabular}{|c|c|c|c|}
\hline $\mathbf{2 0 0 5}-2015$ & Terrestrial border region & Non-border region & Total \\
\hline EU-15 & & & \\
\hline Total change & 4.0 & 4.3 & 4.2 \\
\hline Natural change & 0.7 & 1.4 & 1.2 \\
\hline Net migration & 3.4 & 2.9 & 3.0 \\
\hline EU-13 & & & \\
\hline Total change & -3.5 & -1.2 & -2.5 \\
\hline Natural change & -1.5 & -0.9 & -1.3 \\
\hline Net migration & -1.9 & -0.3 & -1.2 \\
\hline EU-28 & & & \\
\hline Total change & 1.3 & 3.6 & 2.8 \\
\hline Natural change & -0.1 & 1.1 & 0.7 \\
\hline Net migration & 1.4 & 2.5 & 2.1 \\
\hline
\end{tabular}

Table 1. Demographic changes in border and non-border EU regions (2005-2015)

(Data source: Eurostat and DR REGIO, derived from European Commission 2017, 127)

There are several obstacles in cross-border cooperation and they most typically include physical geographic barriers (mountain ranges, rivers etc.) or cultural (e.g. language) differences. In addition, socio-economic inequalities on two sides of a border or inadequate infrastructure linkages (e.g. poor transport connections) could also hinder territorial developments in border regions (ESPON, 2019). The disadvantages of borders as socio-economic barriers can also be measured by monetary indicators. As a recent study highlights, Hungary must calculate with a significant loss of GDP because of the Schengen borders created at the external boundary of the EU (Camagni et al., 2017).

The study area of this paper also belong to the „external boundary” of the EU, and a more intense economic cooperation across the boundary is not only the interest of Hungary and Serbia, but also the European Union. Based on socio-economic indicators border regions can often be considered as peripheral areas in line with the centreperiphery theory (Lang, 2015; Nagy \& Timár, 2017). Although 'periphery' implies some backwardness and underdevelopment, the interpretation of periphery at a macro-regional scale is extremely difficult, since a peripheral border region may be an advanced region from the perspective of another country (Pénzes, 2013; Smetkowski, 2015; Vida \& Dudás 2017, Chapman \& Meliciani, 2018; Iammarino et al., 2018, Tatar et al., 2020). Traditional centre-periphery models (e.g. Rokkan, 1970; Wallerstein, 1974; Bourdieu, 1986) highlight three dimensions of spatial relationship between centres and peripheries: economic, political and cultural. In each dimension core regions are dominant against peripheries, but the latter can also benefit from relative backwardness (e.g. cheaper labour force, stronger or "deeper" local culture) (Blahó, 2012). Peripheral and central status cannot be seen as static concepts and there is a constant change in this relationship (Lang, 2015).

In the East Central European context, the Hungarian-Serbian border region can be classified as a traditional agricultural area, where modern industry arrived late (mainly in the socialist period), and focused predominantly on the processing of agricultural products (e.g. food industry). Such agricultural border regions are very often regarded as peripheries with poor socio-economic indicators as far as demographic conditions, 
balance of migration, level of foreign direct investment, employment rates or income are concerned (Pénzes, 2013; Bujdosó, et al., 2015; Vida \& Dudás, 2017; Gozner et al., 2017; Ilieș et al., 2018; 2019; Deac \& Gozner, 2019; ESPON, 2019; Pregi \& Novotny, 2019; Tatar et al., 2020). Tourism could be considered as an opportunity for peripheries in catching up with more developed regions, which can contribute not only to the economic progress but also to the socio-cultural environment, such as improving the quality of life (Rátz \& Puczkó, 2002; Kovács \& Nagy, 2013; Prokkola et al., 2015). However, different infrastructural and institutional capacities of the two sides, and in many cases the different interests, may further restrict cross-border cooperation. Furthermore, the fact that in many cases border regions are less developed regions of a country, the resulting lack of investment and loss of labour force, often hinders developments.

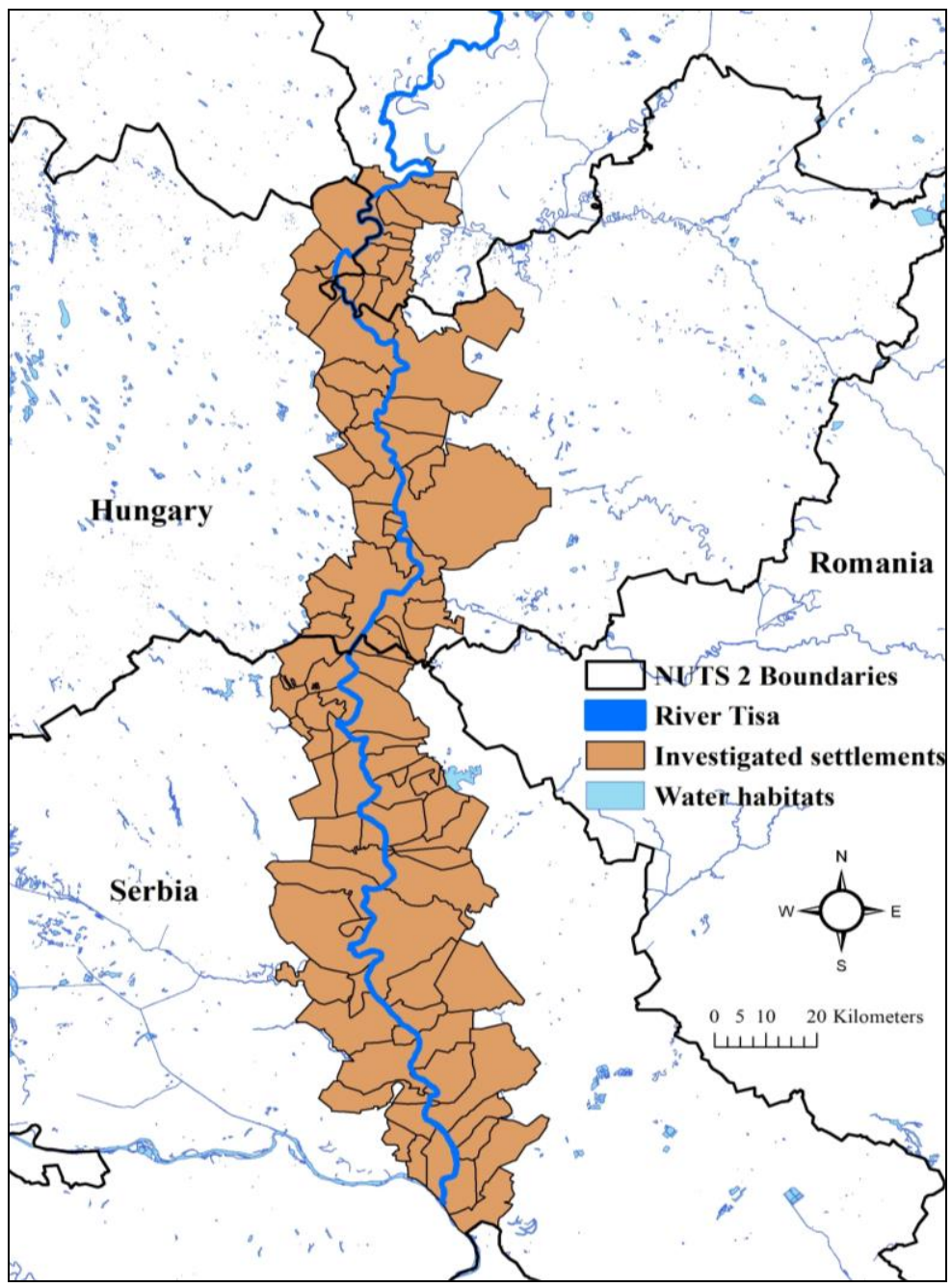

Figure 1. The study area (Source: based on Open Street Map [1,2]; edited by the authors)

The EU has also realised the importance of strengthening links between border areas, and one of the top priorities of cross-border cooperation programs is tourism development, which offers an excellent opportunity for neighbouring border regions to 
develop common touristic programmes (Tarpai, 2010; Muhi \& Remenyik, 2013). Especially alternative forms of tourism (e.g. ecotourism, rural tourism) could be regarded as potential fields of cross-border tourism developments. They are becoming more and more popular nowadays, which, unlike mass tourism, involve the discovery of unspoiled natural environment alongside new or unexplored tourist destinations (Marton et al., 2016). These forms of tourism could especially play key role in the development of border regions that were hermetically cut off from tourist flows in the past. Depending on their characteristics, they could be barriers or filters of tourism development regarding touristic flows, marketing, promotion, the development of touristic infrastructure or creating regional brands (Wieckowski, 2010). In the literature there is a three-fold typology in spatial relations between borders and tourism: the boundary line is far from tourist area, the tourist destination is adjacent to the border on one side, or the tourist zones outstretch or meet at the border line (Gelbman \& Timothy, 2010). The Lower-Tisa Valley as a unique tourist destination belongs to the third category, stretching along the river and connecting two countries on both sides of the Schengen Border.

\section{RESEARCH DESIGN AND METHODOLOGY}

During the research, first the exact boundaries of the case-study area, the LowerTisa Valley had to be defined. In the delimitation all settlements between Tiszakécske (Hungary) and Titel (Serbia) were considered that are directly bordering the river, or lying offside but the centre of the settlement is within 10 kilometres from the Tisa (Figure 1).

Due to geographical proximity these settlements have developed in strong interrelationship with the Tisa in the past, and their economy traditionally hinges on the river. Since the main aim of this study is to assess the potentials and limitations of tourism development along the Lower-Tisa Valley we had to combine different research methods and data sources that were available on both sides of the case-study area, in order to make a comparative study possible. The analysis of socio-demographic conditions was based on data of the 2001 and 2011 population census (2002 in the case of Serbia). For the sake of analyses tourist attractions were collected and catalogued from the Internet websites of settlements and other possible sources (e.g. tourist information websites) $[1,2,3]$ (Indrie et al., 2019). In addition, academic publications focusing on tourism development along major European rivers that connect different countries were selected and analysed.

\section{MAIN RESEARCH FINDINGS}

\section{SOCIO-ECONOMIC CONDITIONS IN THE LOWER-TISA VALLEY}

The delimited area includes 83 settlements (35 on the Hungarian, and 48 on the Serbian side) covering a total area of $6665 \mathrm{~km} 2$, where on the eve of the last census (2011) 640 thousand people lived (Table 1). The size of the settlements varies greatly, the most populous is Szeged (Hungary) with 168 thousand inhabitants, and the smallest one is Mali Pesak (Serbia) with only 94 people. To measure the level of urbanization we ignored the legal definition of towns as it is different in Serbia and Hungary, moreover it is politically often motivated, not always reflecting the actual position of a settlement within the urban hierarchy. Therefore, we considered the statistical threshold of 5 thousand inhabitants to define cities in the study area. As Table 1 shows the urban ratio (83\%) of the Lower-Tisa Valley was significantly higher in both census-years than that of the wider region (in Hungary the Dél-Alföld NUTS2 region and in Serbia Vojvodina).

This means that on average larger settlements prevail in the study area compared to the wider surrounding. The Hungarian side had slightly higher urban ratios both in 2001 and 2011, which is the outcome of the dominance of Szeged, the regional centre of 
Dél-Alföld. On the Serbian side Novi Sad with similar regional functions lies off from the Tisa, which surely sets limitations also for tourism development.

Considering population dynamics both the Serbian and Hungarian sides of the study area experienced population shrinkage between 2001 and 2011, although with different intensity (Figure 2). Despite relatively favourable demographic conditions the Serbian side recorded faster population decrease during the investigated period, which was mainly the outcome of outmigration towards the EU core countries. Biggest relative population losses were recorded in the smallest settlements, like Vojvoda Zimonic (28.2\%), Velebit (-24.3\%) or Jazovo (-24.1\%), but similar dimensions (above $20 \%$ loss) characterised also Bocar, Dala and Sterijino. While none of the Serbian settlements showed population growth, five Hungarian municipalities recorded population increase between 2001 and 2011. Four of them (Deszk, Tiszasziget, Újszentiván, Sándorfalva) are located in the agglomeration of Szeged and they have been aeffected by suburbanisation since the 1990s, and only Cserkeszőlo, the spa-village in the north is lying off.

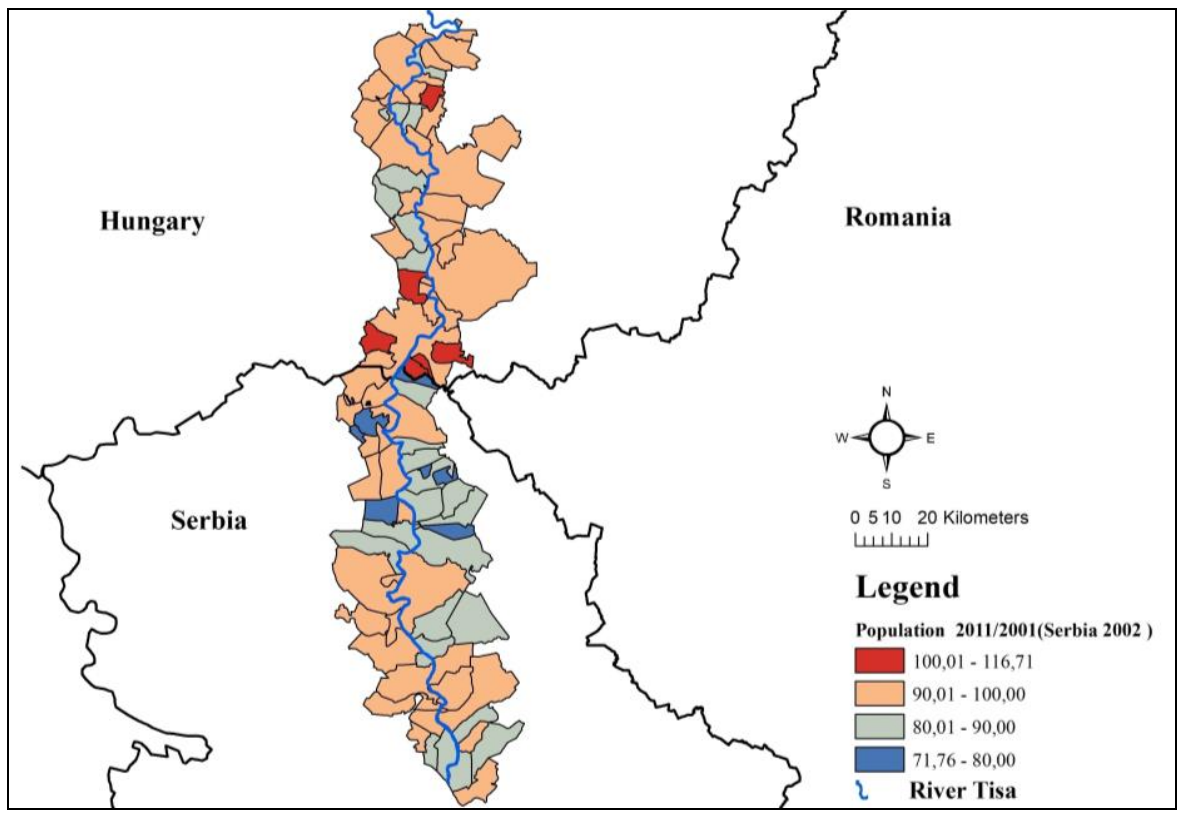

Figure 2. Population change between the investigated two census (Source: based on Open Street Map [1,2], Hungarian Central Statistical Office [4] and Statistical Office of the Republic of Serbia [5];

The age composition of local population is more favourable on the Serbian side. The share of elderly (65+) is lower and the proportion of children (below 15) is higher. This results lower average values of ageing-index in 2011, and if we consider the trends between 2001 and 2011, Serbian settlements perform clearly better in demographic terms (Figure 3). We can observe an opposite trend regarding employment/unemployment on the two sides of the Lower-Tisa Valley. The rate of employment is significantly higher on the Hungarian side, thanks to the recent economic upswing of the country (Figure 4). However, we must also note that there is a group of settlements in the northern section of the study area (called Tiszazug), where the situation is not so favourable. These are smaller municipalities with disadvantageous location, relatively far from major centres (e.g. Szolnok, Kecskemét). The rate of unemployment confirms this picture (Figure 5).

The level of unemployment is nearly twice on the Serbian side and there is a cluster 
of settlements south from Petrovo Selo and Novi Becej where the lack of jobs causes high unemployment rates, e.g. Perlez (21.0\%), Zabalj (19.8\%) or Backo Gradiste (18.2\%).

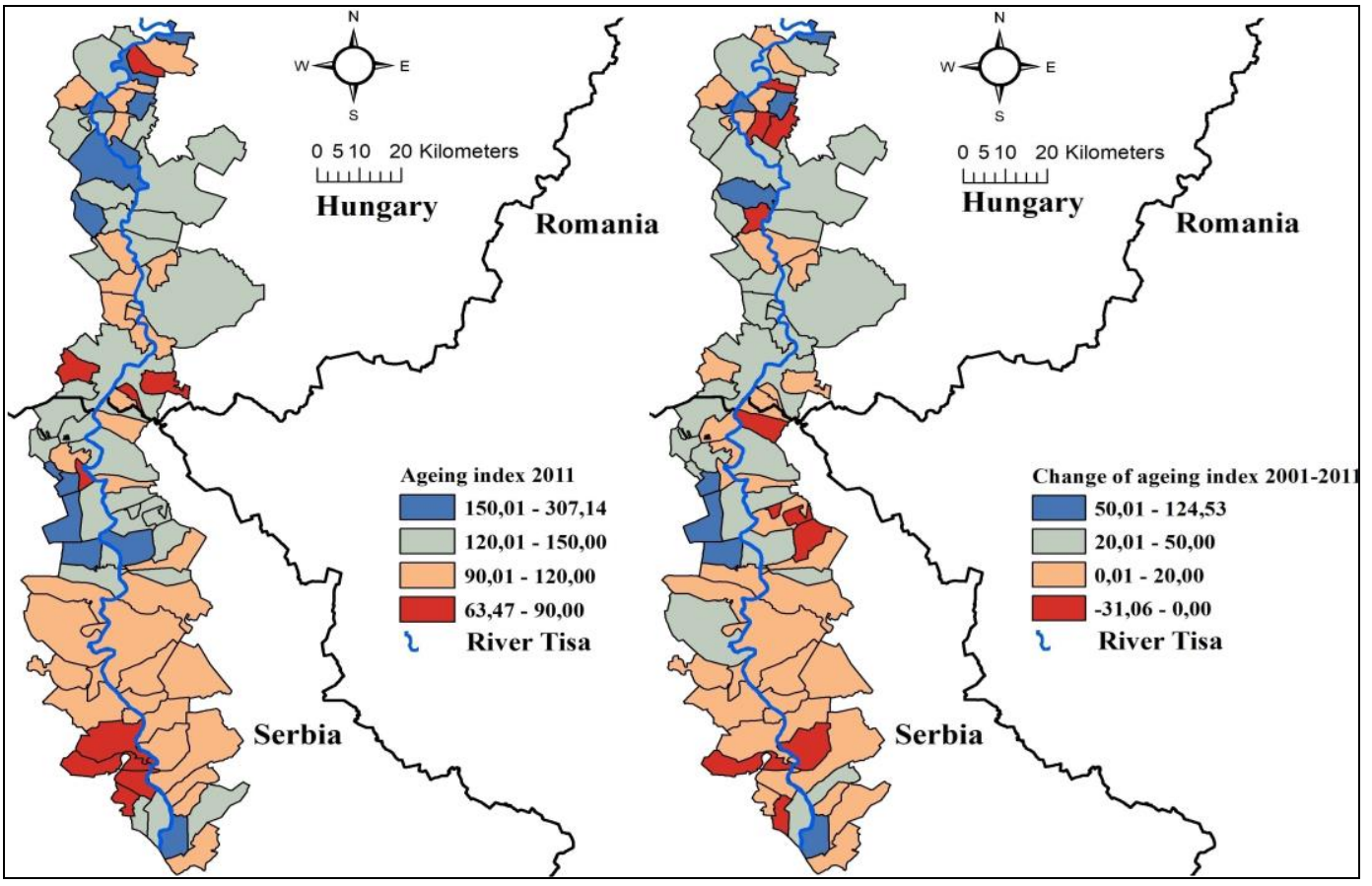

Figure 3. Ageing index patterns in the investigated settlements (Source: based on Open Street Map [1,2], Hungarian Central Statistical Office [4] and Statistical Office of the Republic of Serbia [5]

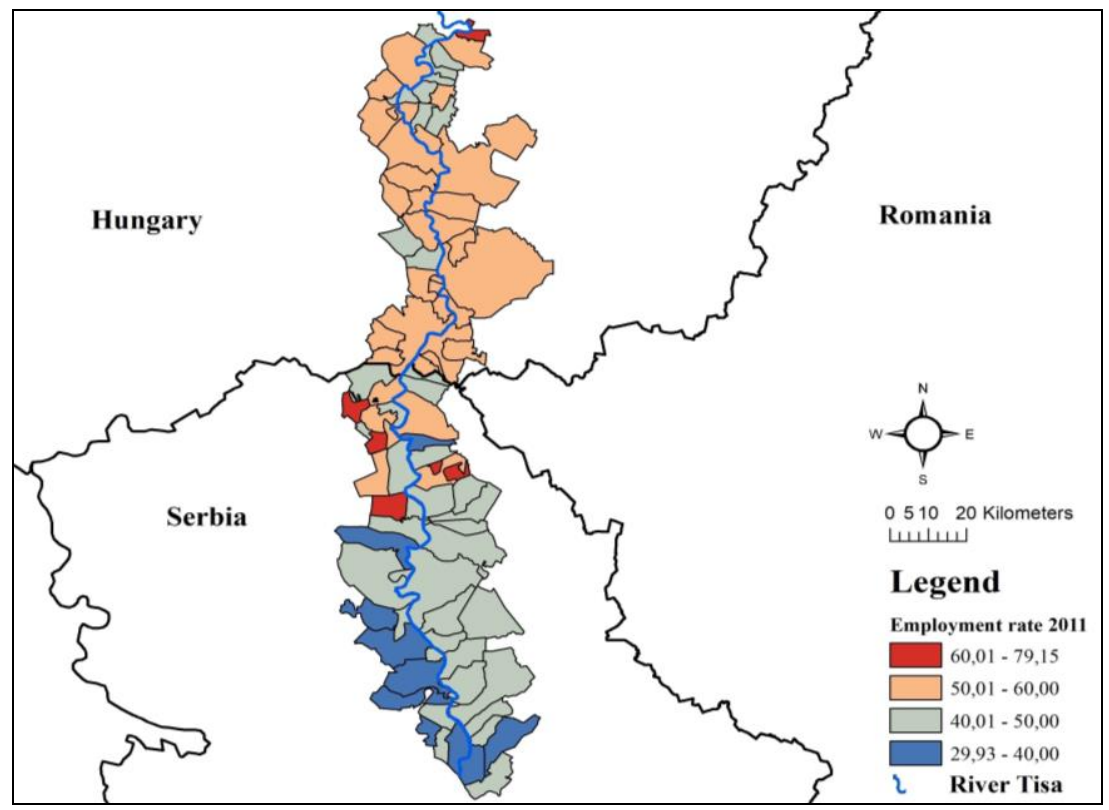

Figure 4. Employment patterns in the investigated settlements (Source: based on Open Street Map [1,2], Hungarian Central Statistical Office [4] and Statistical Office of the Republic of Serbia [5] 


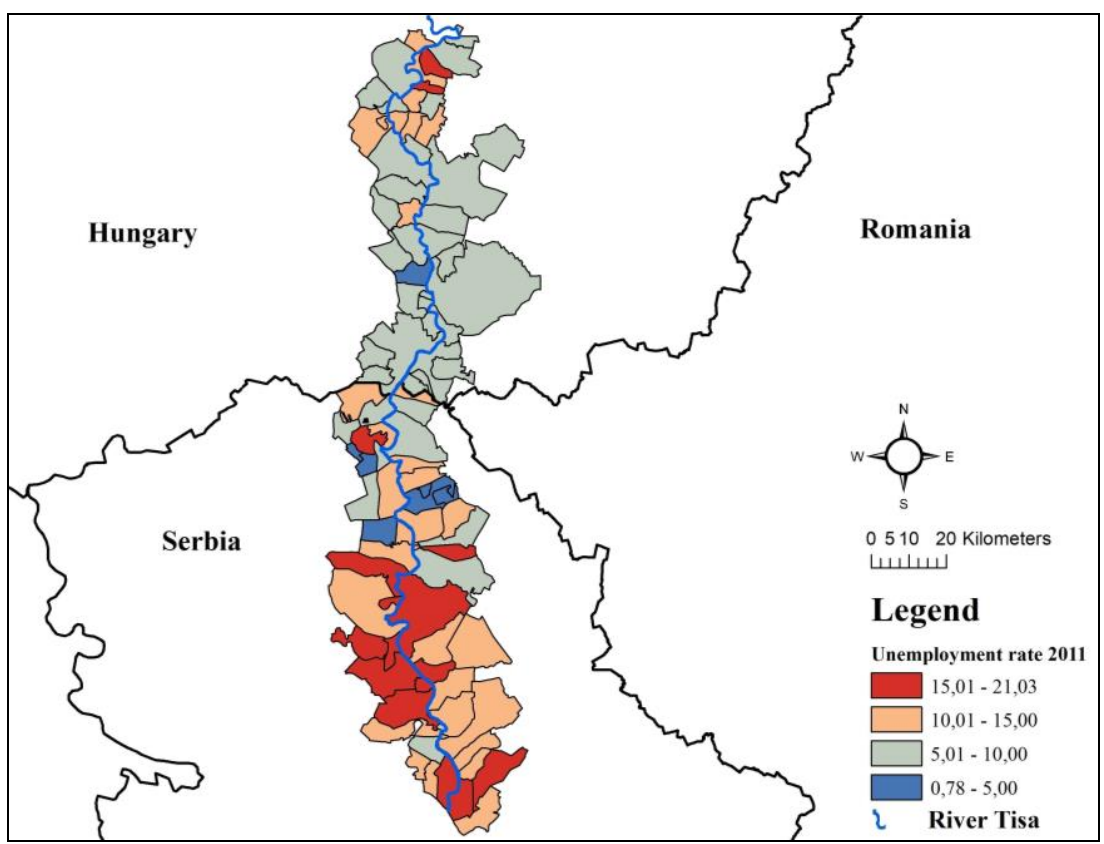

Figure 5. Unemployment patterns in the investigated settlements (Source: based on Open Street Map [1,2], Hungarian Central Statistical Office [4] and Statistical Office of the Republic of Serbia [5]

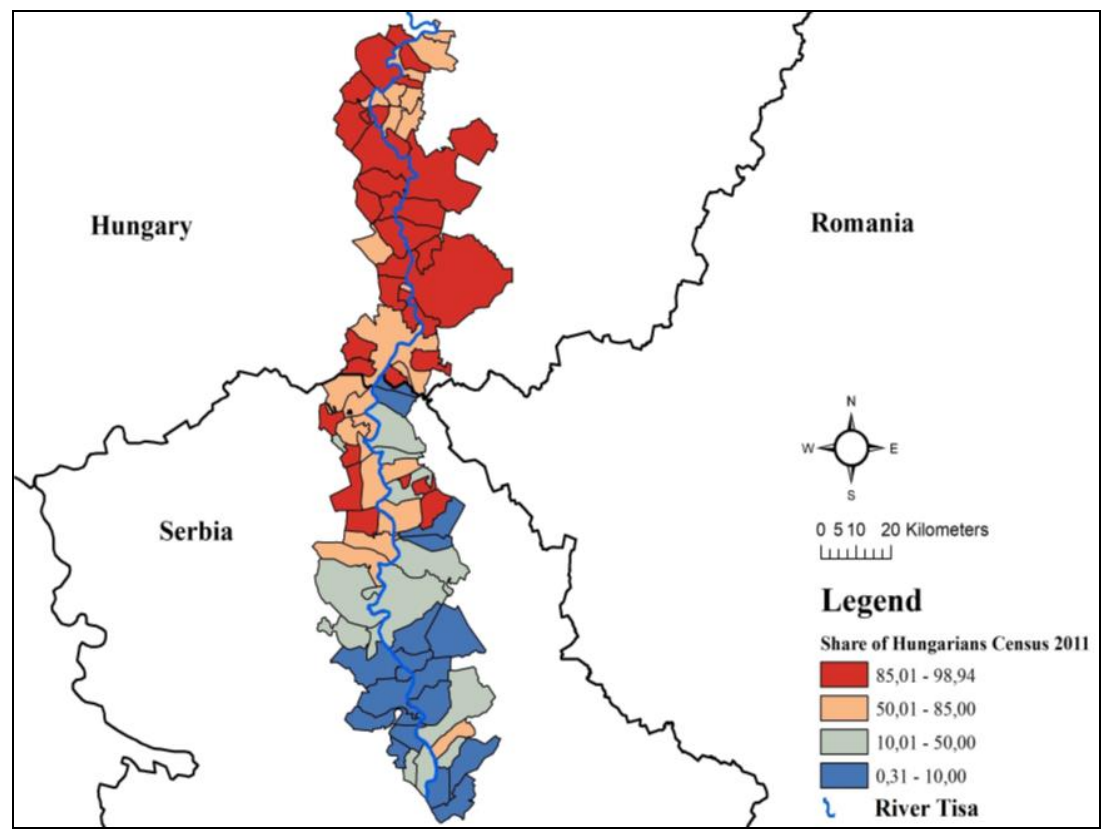

Figure 6. Share of Hungarians in the investigated settlements (Source: based on Open Street Map [1,2], Hungarian Central Statistical Office [4] and Statistical Office of the Republic of Serbia [5];

On the Hungarian side of the research area there is also a group of settlements where unemployment is a problem e.g. Tiszainoka (15.8\%), Cibakháza (15.7\%), Csépa (14.1), Nagyrév (13.0\%). All of these settlements belong to the Tiszazug inner- 
periphery.Regarding ethnicity, the Serbian side is multi-ethnic with substantial share (2011:32\%) of Hungarians, who concentrate mainly in the northern municipalities of Vojvodina, close to the boundary (e.g. Tresnjevac 96.9\%, Gornji Berg 92.4\%, Horgos 82.6\%) (Figure 6). To sum up we can conclude that the Serbian and Hungarian sections of the Lower-Tisa Valley are fairly similar as far as the levels of urbanization and demographic structure of the populations are concerned, even though they have belonged to two different countries over the last century. The economic conditions are clearly worse on the Serbian side with lower employment rates and higher levels of unemployment. This highlights the potentials of tourism development in the future which could enhance job-creation. The presence of Hungarians on both sides of the border and the lack of cultural/language barrier could provide good basis for cross border economic cooperation, including the development of tourism.

The potentials of cross-border tourism development in the Lower-Tisa Valley.

Table 2. Socio-economic indicators for the case-study area and its wider regions (Source: National Census 2001 (2002), 2011, Hungarian Central Statistical Office [4], Budapest and Serbian Statistical Office [5], Belgrade)

\begin{tabular}{|l|c|c|c|c|c|}
\hline & $\begin{array}{c}\text { Hungarian } \\
\text {-side }\end{array}$ & $\begin{array}{c}\text { Serbian } \\
\text {-side }\end{array}$ & $\begin{array}{c}\text { Total case- } \\
\text { study area }\end{array}$ & $\begin{array}{c}\text { Dél-Alföld } \\
\text { NUTS 2 }\end{array}$ & $\begin{array}{c}\text { Vojvodina } \\
\text { NUTS 2 }\end{array}$ \\
\hline Number of settlements & 35 & 48 & $\mathbf{8 3}$ & 254 & 467 \\
\hline $\begin{array}{l}\text { Population number 2001 } \\
\text { (Serbia 2002) }\end{array}$ & 378157 & 297824 & $\mathbf{6 7 5 9 8 1}$ & 1377652 & 2031992 \\
\hline $\begin{array}{l}\text { Urban ratio (\%) 2001 } \\
\text { (Serbia 2002) }\end{array}$ & 85,98 & 79,75 & $\mathbf{8 3 , 2 3}$ & 71,82 & 68,20 \\
\hline Population number 2011 & 365493 & 274737 & $\mathbf{6 4 0 2 3 0}$ & 1297735 & 1931809 \\
\hline $\begin{array}{l}\text { Population change 2001- } \\
\text { 2011 (\%) }\end{array}$ & $-3,35$ & $-7,75$ & $\mathbf{- 5 , 2 9}$ & $-5,80$ & $-4,93$ \\
\hline Share of elderly (65+), 2011 (\%) & 17,11 & 16,67 & $\mathbf{1 6 , 9 6}$ & 17,62 & 16,39 \\
\hline $\begin{array}{l}\text { Share of children (below } \\
\text { 15), 2o11 \% }\end{array}$ & 13,75 & 14,60 & $\mathbf{1 4 , 1 2}$ & 14,01 & 14,36 \\
\hline Ageing-index 2011 & 124,40 & 114,76 & $\mathbf{1 2 0 , 1 3}$ & 125,84 & 114,08 \\
\hline $\begin{array}{l}\text { Change of a geing indes } \\
\text { 2001-2011 (\%) }\end{array}$ & 30,61 & 17,42 & $\mathbf{2 4 , 7 7}$ & 30,56 & 16,26 \\
\hline Employment rate 2011 (\%) & 57,11 & 45,34 & $\mathbf{5 2 , 0 9}$ & 53,72 & 45,40 \\
\hline Unemployment rate 2011 (\%) & 7,29 & 13,15 & $\mathbf{9 , 7 9}$ & 7,89 & 13,35 \\
\hline $\begin{array}{l}\text { Share of Hungarian } \\
\text { ethnicity 2011 }\end{array}$ & 85,13 & 32,28 & $\mathbf{6 2 , 4 6}$ & 86,39 & 13,00 \\
\hline
\end{tabular}

\section{EVALUATING TOURIST ATTRACTIONS IN THE LOWER-TISA VALLEY}

During the research information about existing and possible tourist attractions in the Lower-Tisa Valley have been collected in a structured and systematic way, mostly via the Internet. Some of these attractions are well known, and have already been frequented by tourists, others are still to some extent hidden for visitors. These attractions may provide the basis for long-term tourism development planning in the region (MacCannell, 1976; Michalkó, 2016; Aspridis et al., 2015). The Lower-Tisa Valley offers a great variety of attractions that can be grouped into four broad categories: natural, man-made, tourism services and hospitality (Figure 7). In addition, we distinguish hospitality services that are necessary for tourism development, and we also defined several sub-groups of attractions during the typology (Lew, 1987; Aspridis et al., 2015; Swarbrook, 2002).

Due to the proximity to the river the study-area is extremely rich in natural attractions. The Tisa offers good opportunities for sport tourism including rowing, canoeing and kayaking. In addition, water surfaces are ideal for sportfishing and bathing. There are many natural strands along the river bank, that vary between well-equipped locations (e.g. Tiszakécske or Csongrád) with high quality tourism services (restaurants, accommodation 
etc.) and isolated sand beaches (e.g. Tiszainoka) with calmness and peaceful landscape. Water surfaces sustain an extremely rich flora and fauna. In particular, the yearly "blooming" of the Tisa which is the hatch of vast numbers of mayflies is considered a local natural wonder. The blooming of the Tisa is already a well-known tourist attraction advertised in international catalogues. As an outcome of large-scale flood regulations in the second half of the 19th century there are also many billabongs next to the river providing good opportunities for bird-watching, sportfishing and rowing. Forests and floodplains along the river provide ideal conditions for hiking and other outdoor activities. Among the natural beauties floodplain meadows (e.g. Tiszaalpár, Tiszaug) and arboretums (e.g. Tiszakürt) with excellent habitat for flora provide great potentials for tourism, just like rare geomorphological formations e.g. loess terraces along the Tisa (e.g. Kanjiza) or the Titel Loess Plateau. The Lower-Tisa Valley offers not only natural beauties but also many cultural and historical attractions. Regarding the built environment churches like the Orthodox church in Novi Kneževac (Serbia) or the Catholic church in Cibakháza (Hungary) are excellent examples for valuable historical heritage. There are a lot of mansions and palaces in the area (e.g. the Pallavicini palace in Sándorfalva, or the Marcibanji-Lederer castle in Čoka) that are open to visitors. Museums are important among local tourist attractions with rich exhibitions like the Jozsef Koszta Museum in Szentes, or the Museum Žeravica in Novo Milosevo exhibiting agricultural and other machines. Monuments erected to commemorate past events (e.g. battles, floods) and well preserved folk architectures are also widely spread in the area. In addition, long traditions of pottery (e.g. Hódmezővásárhely, Cserkeszőlő) enrich local cultural attractions. Settlements located in the Lower-Tisa Valley organize many events annually where the focus ranges from local to national and even international relevance (e.g. SZIN music festival in Szeged).

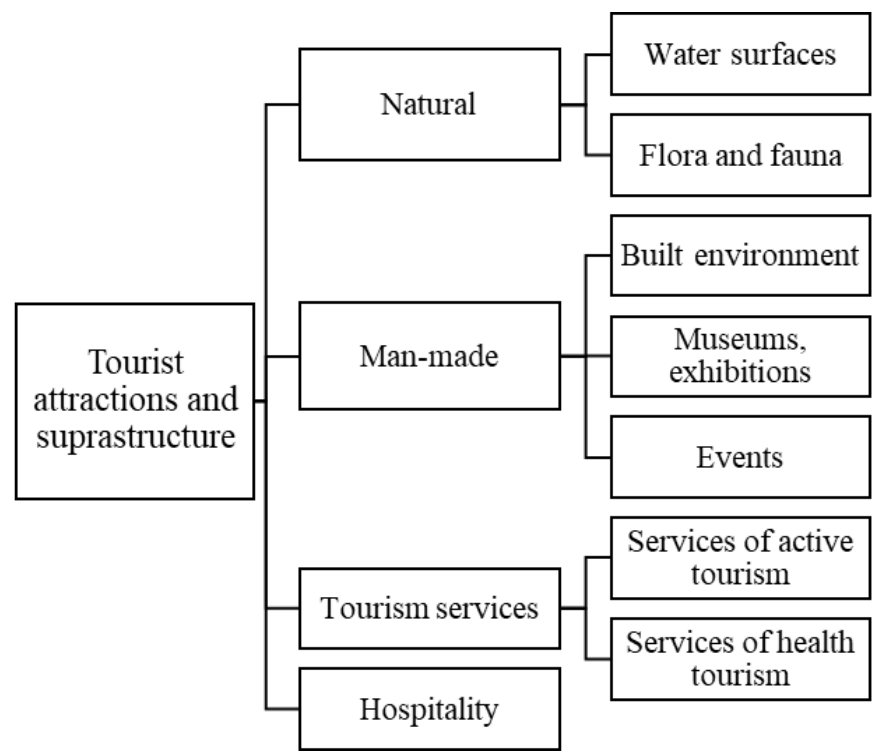

Figure 7. Typology of tourist attractions in the Lower-Tisa Valley (Based on own design)

Most of the settlements organize annual fairs (village feasts), festivals and other events like the horse-driving competition in Cserkeszőlő, the gastronomy festival in Szentes, the sausage festival in Adorjan, or the aivar festival in Deszk. These events are aimed not only to attract visitors but also to preserve local folk-traditions. We have made an inventory of tourist attractions on the Hungarian section of the Lower-Tisa Valley (Table 3). 
Table 3. Tourist attractions on the Hungarian side of the Lower-Tisa Valley based on our own collection, Data source: based on Open Street Map $[1,2]$ and event calendars [3]

\begin{tabular}{|c|c|c|c|c|c|c|c|}
\hline \multicolumn{2}{|c|}{ Natural attractions } & \multicolumn{4}{c|}{ Man-made attractions } & $\begin{array}{c}\text { Total number } \\
\text { of attractions }\end{array}$ \\
\hline $\begin{array}{c}\text { Water surfaces } \\
\text { and strands }\end{array}$ & $\begin{array}{c}\text { Flora and } \\
\text { fauna }\end{array}$ & $\Sigma$ & $\begin{array}{c}\text { Built } \\
\text { environment }\end{array}$ & $\begin{array}{c}\text { Museums, } \\
\text { exhibitions }\end{array}$ & Events & $\Sigma$ & \\
\hline 42 & 30 & 72 & 195 & 53 & 97 & 345 & $\mathbf{4 1 7}$ \\
\hline
\end{tabular}

Similar survey, based on the same methodology on the Serbian section of the river was, unfortunately, not possible. Nevertheless, as Table 3 shows clearly man-made attractions, especially those related to the built environment, significantly outnumber natural attractions. This does not mean, however, that man-made attractions would be more important in future tourism development, rather it is an indication that there is a rich pool of attractions in the area with 417 targets where both natural and man-made attractions complement each other providing tourist a healthy mix of entertainment. Tourist "attractions" in their widest sense include not only beauties of the natural landscape, spectacular scenery, historic sites, museums and local programmes, which are normally associated with the word, but also the services and facilities which cater to the everyday needs of tourists (Lew, 1987). In this respect the study area is relatively underdeveloped. Perhaps the only exception is health tourism which is well-developed due to many spas (e.g. Tiszakécske, Cserkeszőlő, Becej) with high quality thermal water.

Accommodation facilities are available in the region and they range from bed and breakfast, apartments, guest-houses in villages and hotels in towns. Bigger concentrations of tourist accommodation and Airbnb are found in larger cities (Boros et al., 2018), in this case in Szeged (Dudás et al., 2018). As we see, there is a rich collection of tourist attractions in the Lower-Tisa Valley with great variety of spectacles and entertainment, that could easily be developed to thematic routes of sport, health or cultural tourism along the river (Swarbrook, 2002; Michalkó, 2016). However, the management of visitor attractions is rather poor, tourism marketing and branding is still in its infancy (Smith et al., 2019). Moreover, cooperation among municipalities in the field of tourism planning is weak or lacking. Under these circumstances it is no surprise that the number of tourist arrivals in the region is well below the expectations.

\section{DISCUSSION}

Rivers as possible targets of tourism development are increasingly on the agenda in the European Union. As natural corridors through national borders they can connect various tourist destinations on either side of borders. Ecotourism has great potentials in water-related cross-border developments where the unspoiled, unique natural landscape meets with cultural heritages of the region (Rátz \& Puczkó, 2002; Kovács \& Nagy, 2013). In the following we briefly introduce three European good practices in tourism development along rivers crossing international boundaries. We focus here on initiatives which - partly - lies on EU outer boundaries, hence they may provide some experiences for tourism development in the Hungarian-Serbian border regions.

Development of tourism along the Drava river (between Hungary and Croatia)

Along the Hungarian-Croatian border a long-term cooperation between local actors of tourism (e.g. municipalities, national parks, local business sector) has been set up, where mainly EU financed infrastructural developments - such as ports, camp sites, bike routes - were implemented in 2007 and 2008 (Muhi \& Reményik, 2013). As a recent cooperation, the DRAWA international project aimed at developing a water tour along the Drava river between Hungary and Croatia and enhance tourism on both sides of the border. The project was implemented between 2017 and 2019 within the INTERREG V-A 
Hungary-Croatia Co-operation Programme (2014-2020). Within the project natural and artificial barriers of the riverbed were detected, and a mobile application was developed supporting water tourism and shipping on the river. The application was aimed to help water transport (navigating on the river) and tourism development (Ilies et al., 2018), providing up-to-date information about tourist attractions of the region (e.g. information about sites, accommodation, gastronomy and active touristic programmes). Along the route, information boards were also set up in order to inform tourists on both sides of the border [6]. This project could be linked to other tourism related developments in both countries, such as the development of a bicycle route between Pécs (Hungary) and Osijek (Croatia), latter lying on the bank of the Drava river (STRDA 2014).

Development of E-7o water tour between Rotterdam and Klaipeda

As part of the Trans-European Transport Network (TEN-T), the so-called Rotterdam-Klaipeda E-70 water route has earmarked significant resources in the previous and actual EU development cycles (Figure 8).

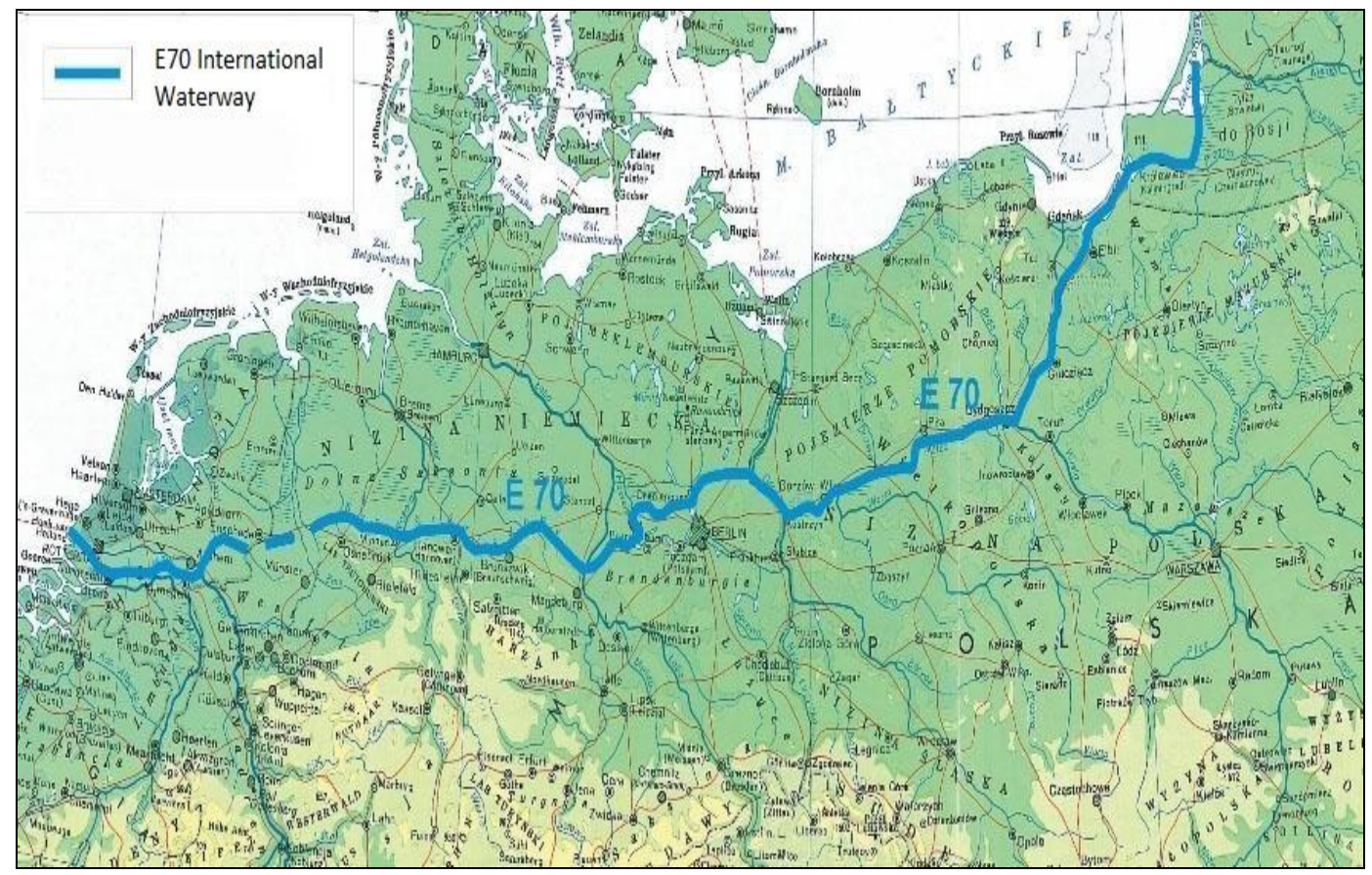

Figure 8. The E-70 waterway connecting Rotterdam and Klaipeda (Source: www.mdwe7o.pl)

The water route is in the line of important East-West transport corridors, which is - together with railways - planned to partly replace highway by 2030 [7]. Water tourism development in the Lithuanian-Russian border (Kropinova, 2013) and integration of the two Lithuanian rivers, Neman and Sesupe into water tourism (Hall, 2017) are also parts of E-70 waterway development. In addition to building the infrastructure along the route for navigation and water tourism (e.g. ports, piers, promenades), the project also aims to draw attention to tourist attractions of the region [8]. Tourism development in the Polish-Lithuanian-Russian border includes touristic products with some added values, such as 'Amber Road' or „The World Amber Way” (Hall, 2017). Attractiveness of this thematic route is aimed to be exploited through appropriate marketing activities and TDM (Tourism Destination Management) tools. 
- The Lithuania - Poland - Russia Cross-border Cooperation Programme 2009-2013

In her paper Kropinova (2013) provides recommendations for tourism development in the outer regions of the EU. Potential tourism development focuses on tourism innovation systems, which are results of actions aimed at creating a new product and consist of a large number of interconnected actors involved in tourism, both represented by public, non-commercial and business sectors (e.g. individuals, organisations, institutions) (Kropinova, 2013, 53; Ilies et al., 2019). Policy recommendations of this cross-border cooperation could be summarised as follows:

a) Introducing new types of tourism products, with special attention to joint, transboundary thematic routes;

b) Introducing new types of activities, which were not developed earlier in the region due to some institutional or infrastructural limitations (e.g. ecotourism);

c) Developing tourism information network between the cross-border regions (common database on the regions' tourism potential);

d) Establishment of a new type of organisation or committee (which tackle down the restrictions on the work of a foreign guide on their territory);

e) Implementation of season extending activities or cooperation (e.g. 'Museums over the borders' programme);

The above best practices reinforce the potentials of cross-border tourism development in the Lower-Tisa valley. In the studied Hungarian-Serbian border region historical, cultural and social traditions as well as unexplored natural attractions provide good opportunities for tourism development, where the Tisa river could serve as an axis, linking municipalities and entrepreneurs on both sides of the border, and enhancing cross-border cooperation among stakeholders.

\section{CONCLUSION}

Since the end of the South Slavic civil war, and the successful European integration of some of the countries the tourism market of South-east Europe and the Balkan region has been dynamically expanding. There are rich national variations in the region in terms of development levels, resources, facilities, services or attractions in tourism (Smith et al., 2018). They provide a solid basis for future tourism development in which cross-border cooperation has many excellent potentials. One of these development scenarios is linked with major rivers crossing the region and connecting its countries including the Danube or the Sava. In the contemporary geopolitical context, crossing the Schengen boundary the Lower-Tisa Valley can be considered as a possible gate towards the Balkans, and a possible development axis in many fields, including tourism. Based on the research results and the international trends documented in the literature we can formulate some recommendations for policy makers, which can be categorised into four groups: management-, tourism-, infrastructure- and education-related ones.

I. Management-related recommendations:

- Local actors in tourism development (e.g. municipalities, tourist boards, other professional organisations and entrepreneurs) should join and act together. For this purpose, a special tourist association should be established uniting actors from both sides of the border.

- Cross-border projects in tourism development should be maintained for a longer period, not just for the project lifetime.

- Tourism-related developments in the area should be harmonised with the goals of the wider tourist destination area.

- Common marketing strategy for the whole tourist region should be elaborated and maintained.

II. Tourism-related recommendations: 
- Emphasis should be placed on cross-border thematic route(s) which require cooperation among actors on both sides of the border.

- Thematic routes should integrate natural, as well as social and cultural values. For example, in the case of the Lower-Tisa Valley, ecotourists may visit the region to take part in kayak or canoe tours along the Tisa River, but the tourist destination should also provide alternative programmes, where tourists can experience local cultural, historical and social values.

- The definition of target groups is vital in the formulation of tourism development plans. In terms of water tourism not just active tourists or professional sportsmen, but families and eco-tourists should be considered as potential target groups.

- Small villages along the river should be provided by special assistance in developing basic services (e.g. catering, accommodation) and attracting more tourists.

III.Infrastructure-related recommendation:

- Sport-related - basic - infrastructural developments are necessary for future tourism development, such as ports, camp sites, bicycle routes or running tracks along the river.

IV. Education-related recommendation:

- The involvement and training of local people in tourism development is important, which would also positively influence the socio-economic conditions of the tourist destinations especially in small peripheral settlements.

As this paper demonstrated unexplored border regions have huge potentials for tourism development, what can, on the one hand, positively influence their economic performance, and on the other hand, provide good opportunities for cross-border cooperation. In the Hungarian-Serbian border region historical, cultural and social traditions provide good opportunities for tourism development, which may enhance cooperation among local actors, including municipalities and entrepreneurs. In future cross-border cooperation the Tisa river deserves particular attention. It can provide the axis of development and generate synergies among - up to now - separated geographical entities. Future research should focus on the connection between landscape aesthetic values (Lontai-Szilágyi et al., 2019) and tourism services on both the Serbian and Hungarian sections of the Lower-Tisa Valley, and help find new objectives for tourism development.

\section{Acknowledgements}

This research was supported by the HUSRB/1602/31/o204-WATERTOUR project, the Hungarian Scientific Research Fund (OTKA) Grant Agreement No. K119710, the Ministry of Human Capacities, Hungary grant agreement 20391-3/2018/FEKUSTRAT, and the Ministry for Innovation and Technology, Hungary grant agreement TUDFO/47138-1/2019-ITM.

\section{REFERENCES}

Aspridis, G., Sdrolias, L., Kimeris, Th., Kyriakou, D. \& Grigoriou, I. (2015). Visitor attraction Management: Is there space for new thinking despite the crisis? The cases of Buckingham Palace and the Museum of Acropolis, In V. Katsoni (Ed.), Cultural Tourism in a Digital Era, pp. 329-347, Springer International Publishing AG Switzerland. DOI: 10.1007/978-3-319-15859-4_28

Blahó, A. (2012). Centre-periphery tensions regarding Central and Eastern Europe, In Fábián, A. (Ed.), A peaceful world is possible: in honour of Judit Balázs, pp. 263-279, University of West Hungary, Sopron.

Boros L., Dudás. G., Kovalcsik. T., Papp S. \& Vida, Gy. (2018): Airbnb in Budapest: analysing spatial patterns and room of hotels and peer-to-peer accommodations. In GeoJournal of Tourism and Geosites, no. 1, vol 21, 26-38.

Bourdieu, P. (1986). The forms of capital, In J. G. Richardson (Ed.), Handbook of theory and research for sociology of education, pp. 241-258, Greenwood Press, Westport.

Bujdosó, Z., Dávid, L., Varga, D., Zhakupov, A., Gyurkó, A. \& Pénzes, J. (2015). Tourism development and crossborder cooperation in the Hungarian-Romanian border region, In GeoJournal of Tourism and Geosites, no. 2, vol 16, pp. 154-164.

Camagni, R., Capello, R., Caragliu, A. \& Toppeta, A. (2017). Quantification of the effects of legal and administrative border obstacles in land border regions, Politecnico di Milano, Milano. doi: 10.2776/25579. 
Chapman, S. \& Meliciani, V. (2018). Explaining regional disparities in Central and Eastern Europe, In Economic of Transition, no. 3, vol. 26, pp. 469-494. http://dx.doi.org/10.1111/ecot.12154

Deac, L.A., Gozner, M. \& Sambou A. (2019). Ethnographic Museums in the Rural Areas of Crișana Region, Romania Keepers of Local Heritage, Tradition and Lifestyle. GeoJournal of Tourism and Geosites, 27(4), 1251-1260.

Dudás G., Kovalcsik T., Boros L., Kovalcsik B., Vida Gy. (2018). Az Airbnb szálláskínálatának jellemzői a megyei jogú városokban. In Területi Statisztika, no. 5, vol. 58, pp. 462-488.

Gelbman, A. \& Timothy, D. (2010). From hostile boundaries to tourist attractions, In Current Issues in Tourism, no. 3, vol. 13, pp. 239-259.

Gozner, M., Tătar, C.F., Stupariu, M. \& Măduta, F.M. (2017). Nature, Photography and Tourism in BihorVlădeasa Mountains (Romania). GeoJournal of Tourism and Geosites, Year X, Volume 20, OradeaGdansk, Romania-Poland, Editura Universităţii din Oradea.

Hall, D.R. (2017), Tourism and geopolitics. Issues and concepts from Central and Eastern Europe, Wallingford: $\mathrm{CAB}$ International.

Ilies, D.C., Buhas, R., Ilies, M., Ilies, A., Gaceu, O., Pop, A.C., Marcu, F., Buhas, S.D., Gozner, M., \& Baias, S. (2018). Sport Activities and Leisure in Nature 2000 Protected Area - Red Valley, Romania. Journal of Environmental Protection and Ecology, 19, No 1, 367-372.

Ilieș, D. C., Oneț, A., Marcu, F.M., Gaceu, O.R., Timar, A., Baias, S., Ilieș, A., Herman, G.V. Costea, M., Țepelea, M., Josan, I. \& Wendt, J. (2018). Investigations regarding the air quality in the historic wooden church in Oradea city, Romania, in Environmental Engineering and Management Journal, Vol.17, no11, pp.2731-2739, http://www.eemj.icpm.tuiasi.ro/pdfs/accepted/204_294_Ilie\%C8\%99_17.pdf.

Ilieș, D.C., Oneț, A., Herman, G.V., Indrie, L., Ilieș, A., Burtă L., Gaceu, O., Marcu, F., Baias, S., Caciora, T., Marcu, A.P., Pavel, O.I., Costea, M., Ilieș, M., Wendt, J. \& Mihincău D. (2019). Exploring the indoor environment of heritage buildings and its role in the conservation of valuable objects, Environmental Engineering and Management Journal, December Vol. 18, No. 12, 2579-2586.

Indrie L., Ilieș, D. C., Oneț, A., Wendt, J. Ilieș, M., Timar, A., Ilieș, A., Baias, S. \& Herman, G.V. (2019). Indoor air quality of museums and conservation of textiles art works. Case study: Salacea Museum House, Romania, Industria textile, Vol. 70 No 1, pp 88-93. Iammarino, S., Rodriguez-Pose, A. \& Storper, M. (2018). Regional inequality in Europe: evidence, theory and policy implications, In Journal of Economic Geography, no. 2, vol. 19, pp. 273-298. https://doi.org/10.1093/jeg/lbyo21.

Kovács, I. \& Nagy, G. (2013). Tourism in peripheric regions - The possibilities of thematic routes, In Analele Universitatii din Oradea - Seria Geografie, no. 2, vol. 23, pp. 220-228.

Kropinova, E.G. (2013). Cooperation between Russia and the EU in the field of innovative development of tourism: the case of the Lithuania - Poland - Russia cross-border cooperation programme, In Baltic Region, no. 4. vol. 5, pp. 48-57. https://doi.org/10.5922/2079-8555-2013-4-5.

Lang, T. (2015). Socio-economic and political responses to regional polarisation and socio-spatial peripheralisation in Central and Eastern Europe: a research agenda, In Hungarian Geographical Bulletin, no. 3 vol. 64, pp. $171-185$.

Lew, A.A. (1987). A framework of tourist attraction research, In Annals of Tourism Research, no. 4, vol. 14, pp. 553-575. https://doi.org/10.1016/0160-7383(87)90071-5.

Lontai-Szilágyi, Z., Bertalan-Balázs, B., Zsiros, B., Vasvári, M., Kumar, S.S., Nilanchal, P., Martonné Erdős, K. \& Szabó, S. (2019). A novel approach of mapping landscape aesthetic value and its validation with rural tourism data, In Hungarian Geographical Bulletin, 68(3), pp. 283-301.

MacCannell, D. (1976). The Tourist: A New Theory of the Leisure Class, New York Shocken Books.

Marton, G., Raffay, Z., Prisztóka, Gy., Raffay, Á. \& Kiss, R. (2016). A Dráva-mente, mint határmenti, periférikus tér turizmusfejlesztésének problémái [The Drava Region, as peripheral border area and challenges of its tourism development], Turisztikai és Vidékfejlesztési Tanulmányok, no. 2, vol. 1, pp. 34-48.

Michalkó, G. (2016). Turizmológia [Tourismology], Akadémiai Kiadó, Budapest.

Muhi, B. \& Reményik, B. (2013). A határ menti és a határon átívelö idegenforgalmi lehetőségek Magyarország, Horvátország és Szerbia esetében [Opportunities in cross-border tourism for Hungary, Croatia and Serbia], In J. Szalma (Ed.), A magyar tudomány napja a Délvidéken - 2013 [Hungarian science day in Délvidék], pp. 541-557, Novi Sad: Hungarian Scientists Society in Vojvodina.

Nagy, Gy., Vida, Gy., Boros L., Ćirić, D. (2019). Decision trees in environmental justice research - a case study on the floods of 2001 and 2010 in Hungary. In Open Geosciences, no. 1, vol. 11, pp. 1025-1034.

Nagy, E. \& Timár, J. (2017). The (re-)production of peripherality in Central and Eastern Europe, European Spatial Research and Policy, no. 2, vol. 24, pp. 5-16. DOI 10.1515/esrp-2017-0006

Pénzes, J. (2013). The dimensions of peripheral areas and their restructuring in Central Europe, Hungarian Geographical Bulletin, 62(4), pp. 373-386.

Pregi, L. \& Novotny, L. (2019). Selective migration of population in functional urban regions of Slovakia, In Journal of Maps, no. 1, vol. 21, pp. 94-102. DOI: 10.1080/17445647.2019.1661880. 
Prokkola, E-K., Zimmerbauer, K. \& Jakola, F. (2015). Performance of regional identity in the implementation of European cross-border initiatives, In European Urban and Regional Studies, no. 1, vol 22, pp. 104-117.

Rátz, T. \& Puczkó, L. (2002). The impacts of tourism, Hame Polythechnic, Hameelinna.

Smetkowski, M. (2015). Spatial patterns of regional economic development in Central and Eastern European countries, In Geographia Polonica, no. 4, vol. 88, pp. 539-555. http://dx.doi.org/10.7163/GPol.oo33

Smith, M., Sulyok, J., Jancsik, A., Puczkó, L., Kiss, K., Sziva, I., Papp-Váry, Á.F. \& Michalkó, G. (2018). Nomen est omen - Tourist image of the Balkans, In Hungarian Geographical Bulletin, no. 2, vol. 67, pp. 173188. DOI: 10.15201/hungeobull.67.2.5

Swarbrooke, J. (2002). The Development and Management of Visitor Attractions, Butterworth-Heinemann, Oxford. https://doi.org/10.1002/jtr.459

Tatar, C.F., Studzieniecki, T., Czimre, K. \& Penzes, J. (2020). Marketing awarenessof crossborder destination - the case study of Bihor-Hajdu/Bihar Euroregion. In GeoJournal of Tourism and Geostites, no. 1, vol. 28, pp. 95-103.

Tarpai, J. (2010). Turisztikai desztinációs menedzsment kialakítása az ukrán-magyar határrégióban [Development of tourism destination management in the Ukrainian-Hungarian border region], In Jelenkori Társadalmi és Gazdasági Folyamatok, no. 1-2, vol. 5, pp. 28-32.

Vida, Gy. \& Dudás G. (2017). Geographical context of the revealed competitiveness of urbanised areas in Hungary excluding the Budapest agglomeration. In Geographica Pannonica, no. 3, vol. 21, pp. 179-190.

Wallerstein, I. (1974). The modern word-system: capitalist agriculture and the origins of the European worldeconomy in the sixteenth century, Academic Press, New York.

Wastl-Walter, D. (2009). Borderlands, In R. Kitchin \& N. Thrift, (Eds.), International Encyclopedia of Human Geography, vol 1. pp. 332-339. Oxford: Elsevier.

Wieckowski, M. (2010). Tourism development in the borderlands of Poland, In Geographia Polonica, no. 2, vol. 83, pp. 67-81.

Zaitseva, N.A., Korneevets, V.S., Kropinova, E.G., Kuznetsova, T.Y. \& Semenova, L.V. (2016). Cross-border movement of people between Russia and Poland and their influence on the economy of border regions, In International Journal of Economics and Financial Issues, no. 4, vol. 6, pp. 1690-1695.

*** Eurostat (2018). Border region, In Methodological manual on territorial typologies, pp. 100-103, Eurostat, Luxembourg.

*** European Commission (2017). My region, my Europe, our future, Secenth report on economic, social and territorial cohesion, European Commission, Brussels.

*** ESPON (2019). State of the European territory, Inception Report, ESPON, Luxembourg.

** STRDA (2014). Cycling tourism in the Hungary-Croatia border area, South Transdanubian Regional Development Agency, Pécs.

https://www.openstreetmap.org/\#map=9/46.2179/20.1215 (Accessed: 08.11.2019).

http://www.geofabrik.de/en/index.html (Accessed: 10.11.2019).

https://www.programturizmus.hu/ (Accessed: 08.08.2019).

http://www.ksh.hu/?lang=en (Accessed: 04.11.2019).

https://www.stat.gov.rs/en-US/ (Accessed: 05.11.2019).

http://ddvizig.hu/en/hirek-ddvizig-en/5afc81b9-bc57-4391-a058-bd5a9023co2f (Accessed: 09.10.2019).

https://financialobserver.eu/poland/polish-inland-waterways-in-progress/ (Accessed: 11.11.2019).

https://mdwe70.pl/en/o-projekcie (Accessed: 08.11.2019).

Submitted:

26.10.2019
Revised:

04.03 .2020
Accepted and published online 10.03.2020 